$$
\begin{gathered}
\text { カテコールアミンのラジオレセプターアッセイ } \\
(1)^{3} \mathrm{H}-\text { norepinephrine を用いての検討 } \\
\text { 京都大学 医学部 第 } 2 \text { 内科 } \\
(\text { 指導 井村裕夫教授) } \\
\text { 大 森 芳 明 }
\end{gathered}
$$

\title{
A Radioreceptor Assay for Catecholamines
}

I. A Study with ${ }^{-3} \mathrm{H}-$ Norepinephrine

\section{Yoshiaki OHMORI}

2nd Medical Clinic Department of Medicine, Medical Faculty, Kyoto University, Kyoto, Japan

Prof. Hiroo Imura

\section{Summary:}

A radioreceptor assay for catecholamines $(\mathrm{CA})$ has been established utilizing the microsomal fraction of bovine myocardium as CA receptors and ${ }^{3} \mathrm{H}$-norepinephrine $\left({ }^{3} \mathrm{H}-\mathrm{NA}\right)$ as a ligand. The bound fraction was separated from the free fraction by filtration through milipore filters. The following results were obtained:

1) The optimal amount of the microsomal fraction was $250 \mu \mathrm{g} /$ tube, when ${ }^{3} \mathrm{H}-\mathrm{NA}$ of 12,000 c.p.m was used. The appropriate conditions for incubation were 2 hours at $37^{\circ} \mathrm{C}$ in a $\mathrm{pH} 7.4$ sucrose solution.

2) By this method, norepinephrine was detectable in the range from 5 to $100 \mathrm{ng} /$ tube.

3) Various compounds with catechol nucleus showed a cross-reaction in this radioreceptor assay system.

4) Alpha-adrenergic blocking agents inhibited the binding of ${ }^{3} \mathrm{H}-\mathrm{NA}$, whereas betablocking agents were ineffective.

These results suggest that the microsomal fraction of bovine myocardium contains alpha-adrenergic receptors which bind the catechol nucleus of CA.

\section{緒言}

Radioimmunoassay（RIA）の開発により，各種ホルモンの微量測定が可能となり，内分泌学は 飛躍的に発展をした。しかし，カテコールアミン（CA）は比較的早期に発見されたホルモンにも かかわらず，その血中微量測定法は，まだ確立されず，その生化学的，薬理学的検索は充分になさ れていない。最近, competitive protein binding assayの一種で, RIAにおける抗体に代る結合蛋 白として，ホルモンレセプターを精製して用いる radioreceptor assay（RRA）が開発され，ins - 
ulin, TSH 等の測定に応用されてきた。しかし，RRAでは生物学的活性のあるホルモンを測定す るという利点はあるが，実用性の面ではRIAに比し劣るので，ホルモン測定法としてはRIA のよ うには用いられていない。しかし，ホルモンの標的細胞のレセプターとの反応の解析，レセプター 数の算定やその調節機構の究明, 抗レセプタ一抗体の発見など, RRAの貢献も大きい。

我々は，血中 CA 測定法の開発と CA レセプタ一の性質の検討を目的として，牛心筋ミクロソー ム分画を用いる CAのRRA を確立し，興味ある知見を得たので報告する。

実験材料及び方法

\section{1）牛心筋ミクロソーム分画の精製}

Lefkowitz ${ }^{1)}$ らの方法に準じて, 屠殺直後の牛左室心筋の内膜, 外膜, 血管などを除去した後, 八 サミで可能な限り細切し, 3 倍量の $0.25 \mathrm{M}$ sucrose 液 $\left(0.001 \mathrm{M} \mathrm{Mg} \mathrm{Cl}_{2}, 0.005 \mathrm{M} \mathrm{Tris} \cdot \mathrm{HCl} \mathrm{p}\right.$ H 7.4）を加え, 電動式テフロンホモジナイザーで, 高速でホモジナイズした。このホモジネートを Beckman 201型の超遠沈機で, 42-1 型のローターを用いて，30,000 r.p.m（78,000×G）で5 分 間遠沈した上清を, 再び, 30,000 r.p.m 60分間遠沈して, 赤褐色のペレット, 即ち, ミクロソーム 分画を得た。そのペレットを $2.5 \mathrm{mg} / \mathrm{ml}$ の割合で，上記 $0.25 \mathrm{M}$ sucrose 液に懸濁して結合蛋白 (B. P）として使用した。なお，上記操作は全て $4{ }^{\circ} \mathrm{C}$ 以下で行った。

\section{2) 放射性 norepinephrine}

$\mathrm{D} \cdot \mathrm{l}\left[7 \cdot{ }^{3} \mathrm{H} 〕\right.$-norepinephrine (Amersham $\left.8.0 \mathrm{Ci} / \mathrm{m} \mathrm{mol}\right)\left({ }^{3} \mathrm{H}-\mathrm{NA}\right)$ を標識ホルモンとし て使用した。

\section{3） RRAの方法}

特に記載した場合を除いて, 標準的な方法としては, B. P $250 \mu \mathrm{g} /$ tube, ${ }^{3} \mathrm{H}-\mathrm{NA} 12,000$ c.p.m. 資料 $100 \mu \mathrm{l}$ を加え, 総量 $300 \mu \mathrm{l}$ とし $, 37^{\circ} \mathrm{C}, 2$ 時間のインキュベーションを行った後, 遊離分画 $(\mathrm{F})$ と結合分画(B)を milipore filter（pore size $0.45 \mathrm{~m} \mu$ ) にて分離した。

\section{4）放射性資料の測定}

上記方法にて得た B を，Bray氏シンチレーターを使用して，Packard 社製液体シンチレーショ ンカウンターにより，放射能の測定を行なった。

\section{実 験 結 果}

\section{1）結合蛋白量の検討}

$7.8 \mu \mathrm{g} /$ tube より $, 2,000 \mathrm{mg} /$ tube のB.P を，0.25M sucrose 液 $100 \mu \mathrm{l}$ に含有するよう調整し， ${ }^{3} \mathrm{H}$ - NA 12,000 c. p.m, $0.25 \mathrm{M}$ sucrose 液 $100 \mu \mathrm{l}$ を加えて, 総量 $300 \mu \mathrm{l}$ とした混合液を, $37^{\circ} \mathrm{C}, 2$ 時間インキュベートした。次いで, 反応液をmilipore filterで, 滤過して, FとBを分離し，その 放射能を測定した。その成績はFig. 1 に示す如く, B.P $31.25 \mu \mathrm{g} /$ tube より $500 \mu \mathrm{g} /$ tubeの間でB. $\mathrm{P}$ と ${ }^{3} \mathrm{H}-\mathrm{NA}$ の結合に直線関係を得た。従って, 我々は, 以後の実験では, B. P $250 \mu \mathrm{g} / \mathrm{tube},{ }^{3} \mathrm{H}-$ NA 12,000 c. p. m, 測定しょうとする資料 $100 \mu \mathrm{l}$ ，総量 $300 \mu \mathrm{l}$ の反応系を用いた。

\section{2) 至適 $\mathrm{pH}$ の決定}

反応液の至適 $\mathrm{pH}$ を決定するため，0.25M sucrose 液を $0.1 \mathrm{~N} ・ \mathrm{HCl}$ で $\mathrm{pH} 6.5$ より $\mathrm{pH} 10.5$ の間 に補正し，上記方法に従い， ${ }^{3} \mathrm{H}-\mathrm{NA}$ と B.P との結合を検討した。その成績はFig. 2 に示す如く で， ${ }^{3} \mathrm{H}$ - NA と B.P の結合は pH 7.2より pH 8.2の間で，良好に認められ，最高の結合は $\mathrm{pH} 7.4$ でみられた。よって，以後の実験は $\mathrm{pH} 7.4$ で行った。 


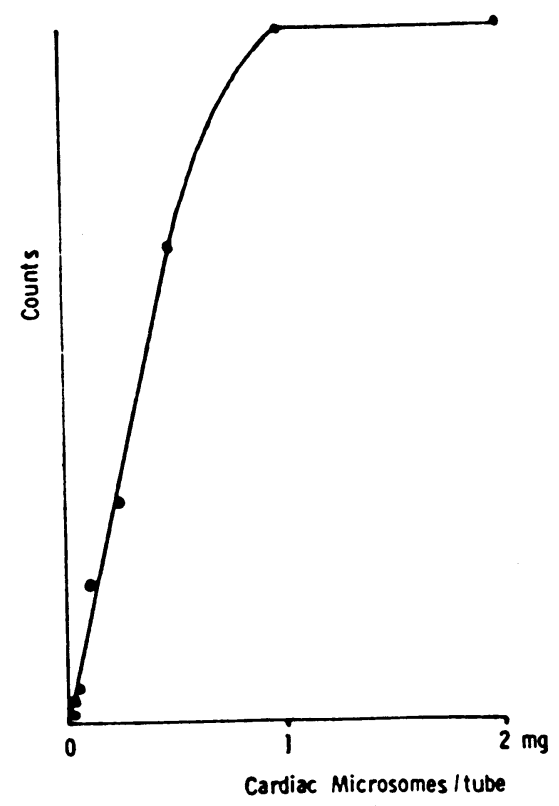

Fig. 1. Binding of ${ }^{3} \mathrm{H}$-norepinephrine to cardiac microsome fraction.

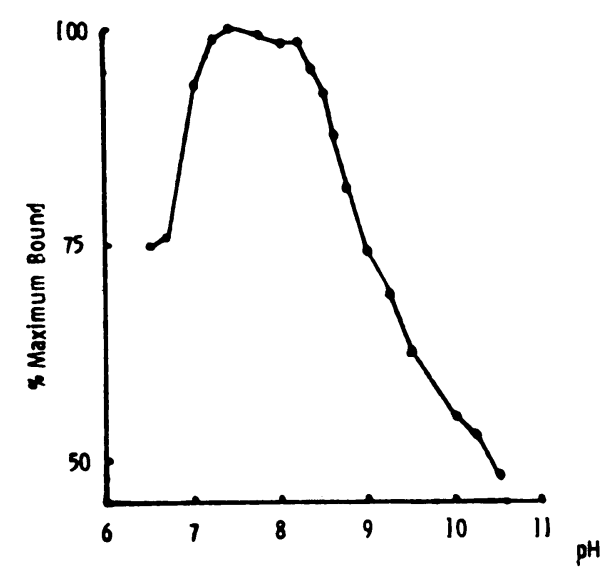

Fig. 2. Effect of $\mathrm{pH}$ on ${ }^{3} \mathrm{H}$-norepinephrine binding to cardiac microsome fraction. 


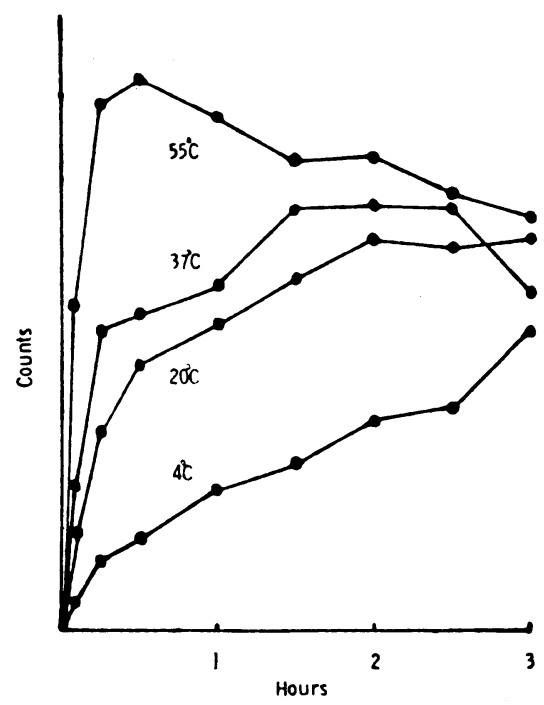

Fig. 3. Time course of ${ }^{3} \mathrm{H}$-norepinephrine binding to cardiac microsome fraction at different temperatures.

\section{3） 反応時間と温度の検討}

${ }^{3} \mathrm{H}$ - NA と B.P の反応を $4{ }^{\circ} \mathrm{C}, 20^{\circ} \mathrm{C}, 37^{\circ} \mathrm{C} ， 55^{\circ} \mathrm{C}$ の温度で，180分まで時間を追って検討した。 その結果はFig. 3 に示す如く $4{ }^{\circ} \mathrm{C} て ゙ は 180$ 分まで，緩徐に， ${ }^{3} \mathrm{H}-\mathrm{NA}$ と B.P との結合は上昇した。 $20^{\circ} \mathrm{C}$ では，60分まで急激に上昇したが，以後 120 分まで上昇カーブは緩徐化し，120分以後，180分ま

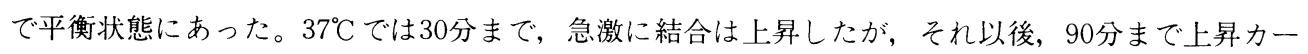

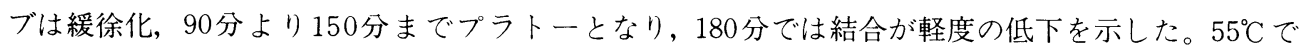
は, 30分まで急速に結合が上昇し, 30分で最高結合となり, 以後時間の経過とともに低下した。各 温度での最高結合は $55^{\circ} \mathrm{C}, 37^{\circ} \mathrm{C}, 20^{\circ} \mathrm{C}, 4{ }^{\circ} \mathrm{C}$ の順に大きく, 最高結合に達する時間は, $55^{\circ} \mathrm{C}, 37^{\circ} \mathrm{C}$, $20^{\circ} \mathrm{C}, 4{ }^{\circ} \mathrm{C}$ の順に短時間であった。以上の成績により，以後インキュベーション温度，時間を $37^{\circ} \mathrm{C}$, 2 時間とした。

\section{4) 標準曲線の検討}

我々のRRAによる, norepinephrine（NA）の標準曲線を検討した。NA $100 \mathrm{pg} / \mathrm{tube} よ り 100 \mu \mathrm{g}$ /tube まで，種々の濃度に添加して， ${ }^{3} \mathrm{H}-\mathrm{NA} と$ B.P との結合への影響を検討した成績を Fig. 4 の (A)に示した。NA $5 \mathrm{ng} /$ tubeより100ng/tubeの間で直線関係にあり, 測定可能範囲と考之られ, 最 小検出量は $5 \mathrm{ng} /$ tube であった。

\section{5) Scatchard plotによる解析}

標準的な方法で， ${ }^{3} \mathrm{H}-\mathrm{NA}, \mathrm{B} . \mathrm{P}$ と $100 \mathrm{pg}$ より $100 \mu \mathrm{g}$ の非標識 NA を反応させ, Scatchard 解析 を行った。その結果はFig. 4 の(B)に示す如く, NAのB.Pに対する反応性は 2 相性であり, high affinity low capacity 部分の平衡定数 $\mathrm{K}_{1}=1.56 \times 10^{7} \mathrm{M}^{-1}$, 最大結合量は $2 \times 10^{-5} \mathrm{M} / \mathrm{g}$ - pellet で あり, low affinity high capacity 部分は $\mathrm{K}_{2}=1.00 \times 10^{4} \mathrm{M}^{-1}$, 最大結合量は $2 \mathrm{M} / \mathrm{g}$-pelletであっ た。なお，0点での ${ }^{3} \mathrm{H}-\mathrm{NA} の$ 結合（B/T ）は7.4\%であった。 


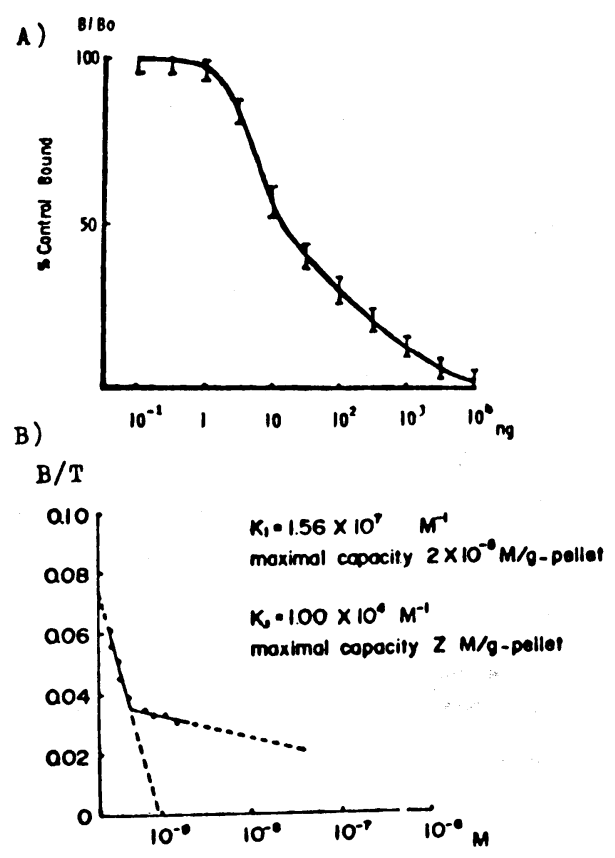

Fig. 4. A): Standard curve in radioreceptor assay of norepinephrine.

B): Scatchard plots of norepinephrine binding to cardiac microsome fraction.

\section{6）種々の薬剤の交叉反応性の検討}

Fig. 5 の(A)に示す如く, 各種濃度の dopamine (DA), NA, epinephrine(A), isoproterenol (Iso) を sucrose 液（pH 7 .4）100 $\mathrm{kl}$ に溶解して, 反応液に加之, $37^{\circ} \mathrm{C}, 2$ 時間インキュベートし, ${ }^{3} \mathrm{H}$ NA と B.P との結合に対する displacement curveを作成し, それら薬剤の相対的結合力の強さを 比較検討した。DA，NA，Aの50\% displacement は10ng/tubeであり，3者間の結合能に有意の差 は認めなかった。しかし, Isoは前 3 者よりも結合親和性は強く, $50 \%$ displacement は $5 \mathrm{ng} / \mathrm{tu}$ 一 be と明らかにNAよりも，小さかった。

次に, 各種濃度の CA 前駆物質, 代謝物質, 昇圧あるいは降圧作用を持つ各種薬剂, 並びにホル モン, すなわち, phenylalanine, tyrosine, l-dopa, 3-o-methylbopa, dopac, homovanilic acid, normetanephrine, metanephrine, vanillylmandelic acid, tyramine, octopamine, alphamethyl dopa, glucagon, ACTH, angiotensin II, reserpine, fusaric acid, trichlormethiazide, spironolactone，等を前記の方法で添加し， ${ }^{3} \mathrm{H}-\mathrm{NA}$ と B.P との結合に対する影響を観察した。

Fig.5の(B)に示寸如く, l-dopa, dopac, al phamethyl dopaのみに抑制効果がみられ,他の薬剤は $1 \mathrm{mg}$ / tube という大量を加えても，抑制効果を示さなかった。 ${ }^{3} \mathrm{H}-\mathrm{NA}$ と B.P との結合に抑制効果を示 した薬䯇は, l-dopa, DA, A, dopac, Isoであり, 全てカテコール核を保持するもののみ, B.P に 対する結合を示した。従って，CAレセプターに対するCAの結合部位はカテコール核に存在する と考えられた。 

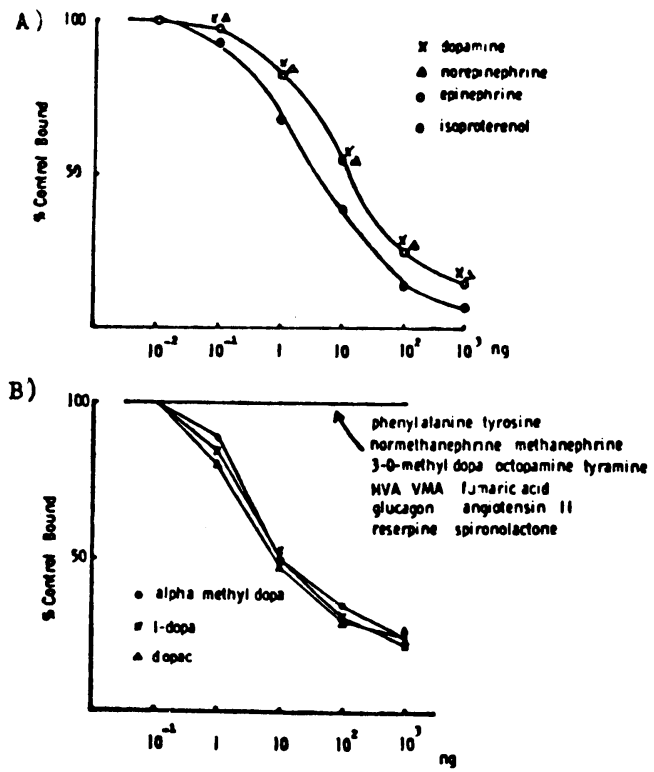

Fig. 5. A): Displacement curves of dopamine, norepinephrine, epinephrine and isoproterenol in radioreceptor assay of norepinephrine.

B): Displacement curves of 1-dopa, dopac, alpha-methyl dopa and other compounds in radioreceptor assay of norepinephrine.

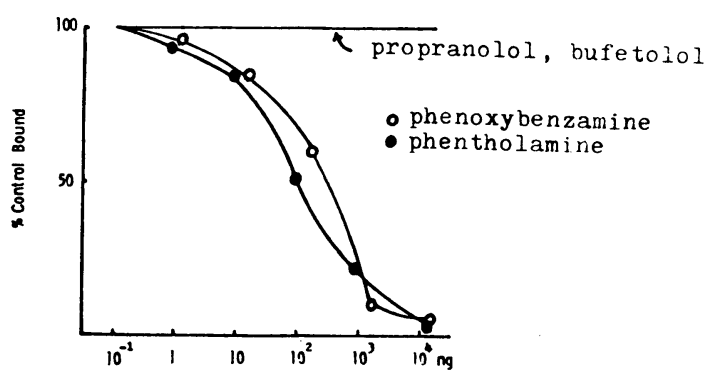

Fig. 6. Blocking action of alpha-(phentholamine, phenoxybenzamine) and beta-(propranolol, bufetolol) adrenergic blocking agents on ${ }^{3} \mathrm{H}$-norepinephrine binding to cardiac microsome fraction. 


\section{7) ${ }^{3} \mathrm{H}-\mathrm{NA}$ と B.P との結合に対する $\alpha$-, 及び $\beta$ - 交感神経遮断剤の効果}

${ }^{3} \mathrm{H}-\mathrm{NA}$ と B.P との結合に対して， $\alpha$ - 遮断剂である phentholamine, phenoxybenzamine, $\beta$ - 遮 断剂である propranolol, bufetolol を前記反応液に添加して, その影響からレセプターの性質を検 討した。その結果, Fig. 6 に示す如く, $\beta$-遮断郕である propranolol, bufetolol は, ${ }^{3} \mathrm{H}-\mathrm{NA}$ と. $\mathrm{P}$ との結合に対して, $10 \mu \mathrm{g} /$ tube の濃度でも, 遮断作用を示さなかったが, $\alpha$ - 遮断剂である phe ntholamine, phenoxybenzamineは共にlng/tubeより遮断作用を示し，50\% displacement は phentholamine で100ng/tube, phenoxybenzamine で200ng/tubeであった。

\section{考察}

現在までに, CAレセプターとして, 肝形質膜 ${ }^{2)}{ }^{3)}$ ), 牛心筋 microsome 分画 ${ }^{1)}$, 犬心筋 microsome ${ }^{5)}$ 猫心筋及び冠血管 ${ }^{6)}$, 脂肪組織 ${ }^{7)}$, 有核赤血球膜 ${ }^{8)}{ }^{97}$ 脾被膜, ${ }^{10}$ ラット小脳 ${ }^{11)}$, などが報告され ている。今回, 我々は比較的容易に，しかも大量に入手しえることから本実験に牛心筋を選択した。

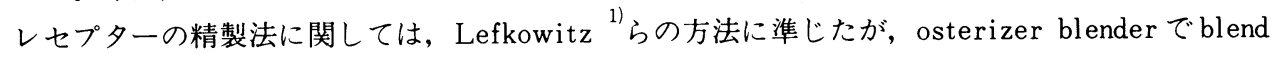
するという過程を省略した。これは, 八サミで可能な限り細切する事によって, 充分に心筋をホモ ジナイズする事ができ，しかも安定したレセプターが得られると考えたからである。事実, 我々 が精製したレセプターは充分な結合能を示したので，適切なCAレセプターの精製法と考える。

$\mathrm{B}$ と Fの分離に関しては, 本論文には示さなかったが, 我々はmilipore filter 法 ${ }^{1)}$, 硫安沈殿 法, polyethylene glycol $\gamma$-globulin 法を検討した。その結果 milipore filter 法を用い良好な成 績を得た。但し, 本法は多数検体の同時処理, 及び, 手技の複雑性などの点で実用性の面で問題を 残しており，今后の改良が必要である。

RRAの反応液として, Lefkowitz ${ }^{1)}$ らはB.P $2.5 \mathrm{mg} /$ tube, ${ }^{3} \mathrm{H}-\mathrm{NA} 50,000$ c.p.m を使用している。 一般に RIA においては, 抗体量, 及び, 標識ホルモン量が少量であればある程, 測定感度の上昇が 認められるので, 我々はレセプターの蛋白量を $250 \mu \mathrm{g} / \mathrm{tube},{ }^{3} \mathrm{H}-\mathrm{NA} 12,000$ c.p .mで行い, 充分な 結合が得られた。従って, B.P, アイソトープ量共に少量の我々のアッセイ系の方が, Lefkowitz の原法 ${ }^{1)}$ より, CA の測定法としては有利であろう。

アッセイ系の至適 $\mathrm{pH}$ の問題については, Lefkowitz ${ }^{1)}$ らも, pH 7.4ないしは7.5を至適と報告 しており, 我々の成績と一致した。哺乳類の血液 PH が7.4前后であることを考慮するとインキュ

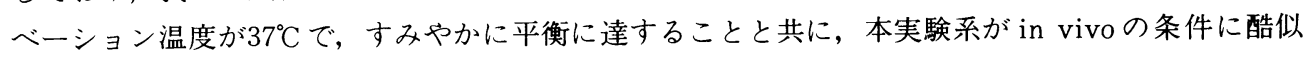
しており興味深い。

反応系におけるCAレセプターとCAの結合はインキュベーション温度の上昇にともなって上昇 した。これは, 本反応が化学的反応の一つであることから, 充分に推察し得る所である。Lefkow$\mathrm{itz}^{1)}$ も同様の検討を行い，37C で180分まで漸増傾向を示したことを報告しているが, 我々の結果 では90分より150分まで平衡状態にあった。これはアッセイ系の B.P 量及び, ${ }^{3} \mathrm{H}-\mathrm{NA}$ 量が, Lef kowitzの系に比して，少量であることによるものかもしれない。なお， $37^{\circ} \mathrm{C} て ゙ 180$ 分， $55^{\circ} \mathrm{C} て ゙ 30$ 分 以后, 結合が漸減傾向を示したのは, 比較的高温でのインキュベーションによるB.Pの変性による ものと推察される。従って, 我々は ${ }^{3} \mathrm{H}-\mathrm{NA}$ と B.P との結合の平衡状態, 及び, B.P の安定性よ

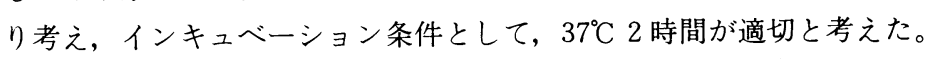

我々のRRA における標準曲線によると, CA の最少検出量は $5 \mathrm{ng} /$ tube であり, 測定可能範囲は $5 \mathrm{ng} /$ tubeより $100 \mathrm{ng} /$ tube であった。一方, 種々の方法で測定された血中 CA 濃度は $100 \mathrm{pg} / \mathrm{ml}$ 前 
后と推定されているので，本法により血中 CA を直接測定のためには，1,000倍以上感度を上昇さ せる事が必要である。従って，この CA のRRA は直ちにCAの測定に応用できるものではない。

Lefkowitz ${ }^{12)}$ らは, 最近, affinity chromatographyを用いて, レセプターの精製, 及び, 可溶化 に成功し，Boが6.2\%から，8.8\%に上昇したことを報告しており，我々もレセプターの純化を行う と共に, ${ }^{3} \mathrm{H}-\mathrm{NA} の$ 代りに, ${ }^{125} \mathrm{I}$ など $\gamma$ 線の使用することも今后の課題と考える。

Scatchard plotで解析したところ, NAのB.Pへの結合は 2 相性であり，この結果は，Lefkow$\mathrm{itz}^{5)}$ の報告と一致する。我々の結果は, high affinity low capacity 部分の平衡定数 $\mathrm{K}_{1}=1.56 \times$ $10^{7} \mathrm{M}^{-1}$ であり, low affinity high capacity 部分の平衡定数 $\mathrm{K}_{2}=2.00 \times 10^{4} \mathrm{M}^{-1}$ であるが, Lefk owitz ${ }^{5)}$ は $\mathrm{K}_{1}=1.04 \times 10^{7} \mathrm{M}^{-1}, \mathrm{~K}_{2}=1.33 \times 10^{6} \mathrm{M}^{-1}$ と報告しており, 我々の成績とほぼ一致してい る。このCAレセプターの平衡定数は他のホルモンの平衡定数に比し, $10^{-2}$ から10-5のオーダー低 い值である。その理由はなお明らかでないが, 例之ば, 神経のシナプスの様に, CA の放出部位か らレセプターまでの距離が非常に近いことから特に不自然ではないと考えられる。非標織ホルモン を添加しない場合の B/T 即ち, Boは我々の成績では7.4\%であり, Lefkowitz ${ }^{5)}$ の $6.2 \%$ に比べ高 值を示した。他のホルモンのRRA と比較して，特に問題があるとは考えられない。

種々の薬剤による ${ }^{3} \mathrm{H}$ - NA と B.P との結合に対する影響についての検討では，その抑制効果は， Iso $>\mathrm{A}=\mathrm{NA}=\mathrm{DA}>1$. dopa $=$ dopac = alpha methyl dopaの順であった。我々の実験でこれら物 質の結合親和性の間に有為の差を認めなかった。A，NA，DA 3 者の心血管系に対する薬理学的 作用を考えると、レセプターに対する結合親和性に大差がないという事は興味深い点である。その 他, phenylalanine, tyrosine, 3-o-methyl dopa, homovanilic acid, normetanephrine, metanephrine, vanillylmanderic acid, tyramine, octopamine, glucagon, ACTH, angiotensin II, reser pine, fusaric acid, trichlormethiazide, spironolactoneは ${ }^{3} \mathrm{H}-\mathrm{NA}$ とB.Pとの結合に対して, 交叉反応を示さなかった。 ${ }^{3} \mathrm{H}-\mathrm{NA}$ と B.P との結合を抑制する薬剂の構造式を検討すると, 注目さ れることは, 結合作用を有するものは, カテコール核を共通構造としていること, また逆に結合し ない薬剤は全て，カテコール核の水酸基がメチル化されている。あるいは，カテコール核そのもの を保持していないなどの構造の相異があることである。従って, 我々は B.Pに対する CA の結合部 位 ${ }^{11)}$ はカテコール核と推測した。

次に, 精製した牛心筋 microsome 分画が $\alpha$ ーレセプターか $\beta$-レセプターかを同定するために, $\alpha$-遮断剂では phentholamine, phenoxybenzamine $\beta$-遮断剂である propranolol, bufetolol 用い て検討したが, ${ }^{3} \mathrm{H}$ - NA とB.P との結合は $\alpha$-遮断剂である phentholamine, phenoxybenzamine で 遮断された。Lefkowitz ${ }^{1)}$ らは牛心筋 microsome 分画を $\alpha$ ーレセプターと報告しており, 我々と全

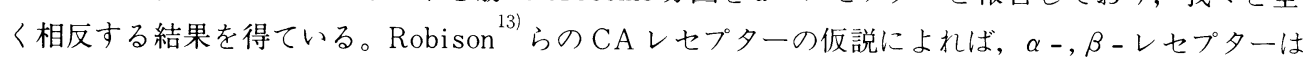
regutalory subunit, catalytic subunitの 2 個の subunit から成り, 隣接した $\alpha$-及び $\beta$-の regul atory subunitにCAが結合し， $\alpha$ ーレセプターはcatalytic subunitである adenyl cyclase 活性の 低下を， $\beta$-レセプターは adenyl cyclase 活性の上昇を促すという。 $\alpha$-及び $\beta$ ーレセプターが隣接

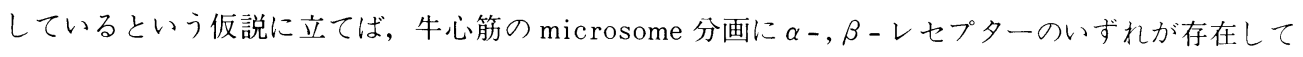
もよいと考えられる。従って, microsome 分画採取の過程の僅かな相違により, 我々は $\beta$-レセプ ターの結合能力を，そして Lefkowitz ${ }^{11}$ らは $\alpha$ レセプタ一の結合能力を失活させたのかも知れな い。しかし，この点に関しては我々の結合蛋白の adenyl cyclase 活性の測定を含めて，今後の検討 が必要である。 


\section{結 論}

血中 $\mathrm{CA}$ の RRA 法の開発を企図し, CA レセプターとして牛心筋 microsome 分画を用いて以下 の結果を得な。

1）結合蛋白としては，250 $\mathrm{g} /$ tube の午心筋 microsome 企画が最適であった。

2) 反応時間としては $37^{\circ} \mathrm{C}, 2$ 時間 $\mathrm{pH} 7.4$ が適当と考えた。

3）本法での norepinephrine の測定範囲は $5 \mathrm{ng} /$ tube より100ng/tube であった。

4）結合蛋白への薬剤の結合はカテコール核を保持した化合物に限定され，CAのレセプターへの 結合部位はカテコール核と考えられた。

5）結合蛋白に対する ${ }^{3} \mathrm{H}-\mathrm{NA} の$ 結合は $\alpha$ - 遮断剂により遮断され， $\beta$ - 遮断剂によっては遮断され なかった。従って，我々の牛心筋 microsome 分画は $\alpha$-交感神経受容体と推測した。

文献

1) Robert, J. Lefkowitz and Edger Haber, "A fraction of ventricular myocardium that has the specificity of the cardiac beta-adrenergic receptor." Proc. Nat. Acad. Sci. USA. vol. 68, No. 8, p.p.1773-1777, $1971 . \quad 2)$ 2) Tusher, K. Ray, "A modified method for the isolation of the plasma membrane from rat liver." Biochemica et Biophysica. vol. 196, p.p. 1-9, 1970.13 3) Marinetti, G.W., Tushar, K. Ray and Vittorio Tomasi, "Glucagon and epinephrine stimulation of adenyl cyclase in isolated rat liver plasma membranes." Biochemical and Biophysical Research Communications. vol. 36, p.p.185-193, 1969.

4) V. Tomasi, S. Koretz, T.K. Ray and J. Dunnick, "Hormone action at the membrane level. II. The binding of epinephrine and glucagon to the rat liver plasma membrane." Biochem. Biophys. Acta. vol. 211, p.p.31-42, $1970 . \quad 5)$ Robert, J. Lefkowitz, Geoffney, W.G. Sharp and Edger Harber, "Specific binding of beta-adrenergic catecholamines to a subcellular fraction from cadiac muscle." The Journal of Biological Chemistry. vol. 248, p.p.342-349, 1972.

6) E.J. Cornish and R.C. Miller, "Comparison of the beta-adrenoceptors in the myocardium and coronary vasculature of the kitten heart." J. Pharm. Pharmac. vol.27, p.p.23-30, $1975 . \quad$ 7) Pairaut, J. and Laudat, M.H., "Selective identification of 'true' beta-adrenergic receptor in the plasma membranes of rat adipsocytes." FEBS Letters. vol. 50. p.p.61-65, $1975 . \quad$ 8) Ivar $\emptyset$ ye and Earl, W. Sutherland, "The effect of epinephrine and other agents on adenyl cyclase in the cell membrane of avian erythrocyte." Biochim. et Biophysica. Acta. vol. 127, p.p.347-354, 1966. 9) M. Schramm, H. Feinstein, E. Naim, M. Lang and M. Lasser, "Epinephrine binding to the catecholamine receptor and activation of the adenylate cyclase in erythrocyte membrane." Proc. Nat. Acad. Sci. USA. vol. 69, p.p.523-527, 1972.

10) Saba Fisher de Plazas and Eduard de Robertis, "Isolation of a proteolipid from spleen capsule binding $( \pm)-\left({ }^{3} \mathrm{H}\right)$-norepinephrine." Biochim. Biophys. Acta. vol. 266, p.p.246-254, 1972.

11) 稲葉 稔： “カテコールアミンの radioreceptor assay" 日本臨床, 〜34巻 p.p.73-78, 1976.

12) Robert, J. Lefkowitz, Edgar Haber and Donald O’Hara, "Identification of the cardiac beta-adrenergic receptor protein; solubilization and purification by affinity chromatography." Proc. Nat. Acad. USA. vol. 69, p.p.2828-2832, 1972. 
13) Robison, G.A., Butcher, R.W. and Sutherland, E.W., "Adenyl cyclase as an adrenergic receptor." Ann. N.Y. Acad. Sci. vol. 139, p.p.703-723, 1967. 